\title{
Geoffrey of Monmouth's De gestis Britonum and Twelfth-Century Romance
}

\author{
Françoise Le Saux
}

Geoffrey of Monmouth's De gestis Britonum had a long and influential afterlife. The work was exploited to endow Anglo-Norman Britain with a foundation myth on which to build a common (though not unproblematic) political identity, giving rise to a new historiographical tradition in Latin, French, and English. At the same time, the great deeds of past British kings form a treasure house of narratives, with the figure of King Arthur at the heart of a new literary phenomenon, the Arthurian romance.

The entertainment potential of the $D G B$ is flagged up by Geoffrey of Monmouth himself in his prologue, where he sketches a context of oral tradition and popular story-telling "about Arthur and the many others who succeeded after the Incarnation" related "by many people as if they had been entertainingly and memorably written down". ${ }^{\text {The }}$ exact nature of this pre-existing narrative tradition is not specified, though the archivolt of the Porta della Peschiera of Modena Cathedral, depicting a scene where Arthur and his knights appear to be attacking a castle to free the captive Winlogee (Guinevere?), is proof of the popularity of tales of Arthur in western Europe by $1120-40 .^{2}$ The huge success of the $D G B$ therefore reinforced and reshaped an already existing tradition, and as such was instrumental in the flowering of the courtly Arthurian romances of the latter 12th century. Geoffrey of Monmouth made King Arthur enter the Latinate cultural mainstream. His later VM, by contrast, failed to work the same magic for Merlin, its central character, and had no discernable impact on 12th-century romance.

An important contributory factor to the long-term success of the $D G B$ was its rapid integration into the vernacular culture of medieval, francophone England. Geoffrey of Monmouth lived at a time of social and cultural ferment. The aftermath of the Norman Conquest had given rise to a network of baronial

$1 \quad D G B$, Prologus 1.5-7: "de Arturo ceterisque compluribus qui post incarnationem successerunt ... a multis populis quasi inscripta iocunde et memoriter".

2 See N.J. Lacy, “The Arthurian Legend Before Chrétien de Troyes”, in N.J. Lacy and J.T. Grimbert (eds.), A Companion to Chrétien de Troyes, Cambridge, 2005, pp. 43-51. 
courts that extended active patronage to writers in the French language and supported a wave of translations from the Latin of authoritative, learned works such as saints' lives, scientific texts, and histories. ${ }^{3}$ This activity contributed to an increased confidence in the French vernacular as a means of literary expression. The extent to which the Anglo-Norman world was attuned to the potential of translation is apparent in Geoffrey of Monmouth's account of his obtaining of his source from Walter of Oxford. ${ }^{4}$ The $D G B$ is presented as a Latin translation of a vernacular authority in a Brittonic language - "a very old book in the British tongue". ${ }^{5}$ This authoritative source is unfamiliar, in the sense that it does not belong to the Greco-Roman mainstream, while the extreme age of the liber vetustissimus, the "very old book", endows it with a validity within its own purview that implicitly trumps Latin histories. Geoffrey's audience would have had little difficulty in accepting such a scenario, as the Anglo-Normans were aware of the long-standing tradition of vernacular literacy in their new homeland, in Irish and English as well as in Welsh. Moreover, even though English had lost its status, the translation culture of pre-Conquest England offered intellectual and conceptual structures that eased the effort of making Latin texts available to a non-Latinate francophone audience. Geoffrey could rely on the willingness of his readers to accept the existence of authoritative texts written in a vernacular to an extent that might not have been quite as true in continental France at the same period.

A noteworthy aspect of the prologue of the $D G B$, along with its inversion of the direction of translatio studii, is its challenging of the presumption of aesthetic superiority of Latin over the vernacular. The supposedly "very old book" is written perpulchris orationibus, that is, with elegance and in the most beautiful style; this exquisite discourse (quite improbably) is itself placed continue et ex ordine, "in a continuous chronological order". ${ }^{6}$ In other words, it

3 See M.D. Legge, Anglo-Norman Literature and its Background, Oxford, 1963; I. Short, "Patrons and Polyglots: French Literature in 12th-Century England", Anglo-Norman Studies 14 (1992), 229-49; and on Latin translation in early Anglo-Norman England, B. O'Brien, Reversing Babel: Translation among the English during an Age of Conquests, c. 800 to c. 1200, Lanham, MD and Newark, 2011. On the specifically socio-linguistic aspect, see also M. Banniard, "Du latin des illettrés au roman des lettrés. La question des niveaux de langue en France (VIII - $-X I I^{\mathrm{e}}$ siècle)", in P. Von Moos (ed.), Entre Babel et Pentecôte, Différences linguistiques et communication orale avant la modernité (VIII ${ }^{e}-X V I^{e}$ s.), Berlin, 2008, pp. 269-86.

$4 D G B$, Prologus 2.9-15: "Optulit Walterus Oxenefordensis archidiaconus, uir ... in exoticis hystoriis eruditus, quondam Britannici sermonis librum uetustissimum qui ... actus omnium continue et ex ordine perpulchris orationibus proponebat. Rogatu itaque illius ductus, ... codicem illum in Latinum sermonem transferre curaui."

$5 D G B$, Prologus 2.10.

$6 D G B$, Prologus 2.11-12. 
has all the hallmarks of the Latin classics that formed the basis of medieval literacy - the works of a Lucan, a Sallust, a Virgil - without being indebted to them. Moreover, translation into Latin is not synonymous with improvement of any sort, but of loss. Geoffrey dismissively refers to his own, Latin style as rustic (agresti ... stilo), further underscoring the superiority of the Brittonic source. ${ }^{7}$ This apparently very conventional use of the humility topos in the prologue is also an endorsement of the vernacular as an effective medium of authoritative discourse.

When the $D G B$ was disseminated in the late 110os, the Anglo-Norman world was already active in the production of didactic and scientific texts in the French language, with writers such as Philippe de Thaun composing his Comput (1113), a technical treatise on the calendar in hexasyllabic couplets, and Bestiary (between 1121 and 1139, in mixed verse form) under the patronage of the English court. Hagiography was also a popular choice for French adaptations, with Benedeit's Voyage of St Brendan (c.1118-21) being one of the earliest surviving saints' lives in French. ${ }^{8}$ Geoffrey of Monmouth's stance in his prologue is thus in tune with the cultural mood of early 12th-century England; and while it would be an exaggeration to suggest that the prologue to the $D G B$ contained an open invitation to further the chain of transmission through translation that Geoffrey purported to have initiated, it is unsurprising that his work was itself swiftly translated into French.

The first mention of a French vernacular history (geste) of the British people appears in Geffrei Gaimar's Estoire des Engleis, of which it may once have formed the first Book; a first redaction of this work, dated to 1137, was revised in $1141 .{ }^{9}$ In his epilogue, Gaimar acknowledges the help of his patroness Constance fitz Gilbert in procuring the English, French, and Latin sources on which he based his account. ${ }^{10}$ These sources unmistakably include a version of the $D G B$ :

$7 \quad D G B$, Prologus 2.13.

8 On hagiography in the Anglo-Norman domain, see F. Laurent, Plaire et édifier: Les récits hagiographiques composés en Angleterre aux XII ${ }^{e}$ et XIII ${ }^{e}$ siècles, Paris, 1998. For a concise contextual study of hagiography in the Middle Ages, see F. Laurent, L. Mathey-Maille, and M. Szkilnik, "L'hagiographie au service de l'histoire: enjeux et problématique", in F. Laurent, L. Mathey-Maille, and M. Szkilnik (eds.), Des saints et des rois. L'hagiographie au service de l'histoire, Paris, 2014, pp. 9-21.

9 See Geffrei Gaimar, Estoire des Engleis, ed. and trans. I. Short, Estoire des Engleis / History of the English, Oxford, 2009, pp. $\mathrm{x}-\mathrm{xii}$ and xxii-xxxii.

10 Geffrei Gaimar, Estoire, ed. Short, pp. 348-5o, ll. 6435-82. 
Geoffrey Gaimar made a written copy of this book and added to it the supplementary material that the Welsh had omitted, for he had previously obtained, be it rightfully or wrongfully, the good book of Oxford that belonged to archdeacon Walter, and with this he made considerable improvements to his own book. ${ }^{11}$

It would appear from these lines that Gaimar had supplemented an already drafted history of the Britons with material from Geoffrey's work, misidentified as the liber vetustissimus itself, rather than having actually translated the entirety of the $D G B$, a reasonable conjecture considering the closeness of the dates of composition of the two texts. ${ }^{12}$ As this work is now lost, the extent and nature of its indebtedness to Geoffrey's work cannot be known. However, Gaimar appears to have been in sympathy with Geoffrey's attractive way of depicting the past, and may have been directly influenced by it in his Estoire des Engleis.

Gaimar closes his narrative with a challenge to his rival David to continue his narrative with an account of the reign of Henry I, where he outlines what he himself would include in this sequel:

[Gaimar] could compose a verse account of the finest exploits, namely, the love affairs and the courting, the drinking and the hunting, the festivities and the pomp and ceremony, the acts of generosity and the displays of wealth, the entourage of noble and valiant knights that the king maintained, and the generous presents that he distributed. This is indeed the sort of material that should be celebrated in poetry, with nothing omitted and nothing passed over. ${ }^{13}$

The features highlighted by Gaimar in this passage are recognizably those that present-day scholarship associates with the romance. They are also prominent features in key episodes of the $D G B$, in particular in the Arthurian section.

11 Geffrei Gaimar, Estoire, ed. Short, p. 349, ll. 6459-66: "Geffrai Gaimar cel livre escri[s]t / [e] les transsa[n]dances i mist / Ke li Waleis ourent leissé / K[ë] il aveit ainz purchacé - / $\mathrm{U}$ fust a dreit u fust a tort - / Le bon livre dë Oxeford / Ki fust Walter l'arcedaien, / Sin amendat son livre bien."

12 See I. Short, "Gaimar's Epilogue and Geoffrey of Monmouth's Liber vestustissimus", Speculum 69:2 (1994), 323-43.

13 Geffrei Gaimar, Estoire, ed. Short, p. 352, ll. 6510-18: "Des plus bels faiz pot vers trover: / Ço est d'amur e dosnaier, / Del gaber e de boscheier, / E de festes e des noblesces, / Des largetez e des richesces / E del barnage k'il mena / Des larges dons k[ë] il dona: / D'iço cevreit hom bien chanter, / Nient leissi[e]r ne trespasser." 
Gaimar's epilogue points to an emerging set of expectations on the part of the audience of a historical text in French in the 12th century, which he strove to satisfy in his Estoire.

Gaimar's work exhibits a number of proto-romance features. ${ }^{14}$ The Estoire adds three major interpolations to the main historical sources used, all three of which feature a striking female character: the wronged heiress Argentille, the wife of Buern Bucecarl, and King Edgar's scheming queen Ælfthryth. As Ian Short points out in his introduction to the Estoire, Gaimar's depiction of women is noticeably free of misogyny. ${ }^{15}$ The image given of the young Elfthryth in particular is that of a courtly lady of romance, beautiful, well-educated, wise, and gracious in her speech, ${ }^{16}$ and generally so charming and well-bred "that no one could ever discover any discourtesy, jealousy or contempt in her, so discreet was she in her behavior". ${ }^{17}$ Her beauty is such that the love-stricken Æthelwald is convinced she is a fairy rather than a human woman (p. 200, 1l. 3661-62). Ælfthryth's luxurious apparel as she comes to court to marry King Edgar is described in detail, from the precious ring on her finger to the long train to her hooded gown under her miniver-lined cloak (p. 212, ll. 3882-91). This vignette culminates with the narrator exclaiming:

"Hey!" - says Gaimar - "I have no wish to expatiate on her beauty and risk delaying [my narrative]. Were I to spend the whole day, from dawn to dusk, recounting the truth of the matter, I would not succeed in telling or describing even a small fraction of her beauty."18

Lavish descriptions of court life and state events also make an appearance in the reign of William Rufus, whose barons are presented in hyperbolic terms (pp. 316-20, ll. 5859-5908) while the king is described in terms evocative of King Arthur himself, attracting a huge number of retainers from overseas (p. 320, ll. 5909-16) and holding a sumptuous, grand crown-wearing ceremony at Whitsun, where he distributes great gifts (pp. 324-28, 1l. 5975-6o54). Gaimar

14 See, for example, A. Press, "The Precocious Courtesy of Geoffrey Gaimar", in G.S. Burgess (ed.), Court and Poet: Selected Proceedings of the Third Congress of the International Courtly Literature Society, Liverpool, 1981, pp. 267-76; see also Geffrei Gaimar, Estoire, ed. Short, pp. xli-xlii.

15 Geffrei Gaimar, Estoire, ed. Short, p. xli.

16 Geffrei Gaimar, Estoire, ed. Short, p. 204, ll. 3746-56.

17 Geffrei Gaimar, Estoire, ed. Short, p. 204, ll. 3757-6o: "k'unches nul hom de nul'envie / ne d'eschar ne de vilainie / ne pout en lui rien trover / si ert sage de sei garder."

18 Geffrei Gaimar, Estoire, ed. Short, p. 212, ll. 3893-98: “'Ho!' feit Gaimar, 'ne rois parler / De sa bealté pur demurer. / Si jo disaie tut le veir / Dés le matin deskë al seir / N'avaraie dit ne aconté / La tierce part de sa bealté." 
relates anecdotes of the king's generosity and sense of humor; his courtliness is illustrated by the story of the entire royal court cropping their hair in solidarity with Walter Giffard and his men, starting a new fashion (pp. $328-30$, 1l. 6o77-6102). The Arthurian connotations to the account of William Rufus's Whitsun court of 1099 are inescapable. ${ }^{19}$

A number of French verse translations and adaptations of the $D G B$, known as Bruts, were made over the course of the 12th century. Using as their main source Geoffrey's vulgate version of the $D G B$ or a Latin rewriting of it (especially the First Variant Version), most of these texts have only survived as fragments. ${ }^{20}$ Only one of these verse translations has come down to us in its entirety: the Roman de Brut, by the Jersey-born cleric Wace (1155). Wace's Roman de Brut is a landmark in medieval French literature, and its success was such that other 12th-century translations into French of the $D G B$ probably could not compete. The Roman de Brut has come down to us in over 30 manuscripts, 19 of which are complete or near-complete: a very large number for a non-religious work. ${ }^{21}$ Despite the title by which it is now known, this is not a romance in the currently accepted generic sense of a work of fiction with a marked interest in the psychology of the central characters, but rather a mise en romanz, an adapted translation into the French language: within the poem, the work is referred to as the geste des Bretuns, "deeds of the Britons", a title echoing that of the vulgate version of Geoffrey of Monmouth's De gestis Britonum. Composed in octosyllabic couplets, it is 14,866 lines long, over 4000 of which recount the reign of King Arthur.

In the Roman de Brut, as in the $D G B$, Arthur is just one king in a long line. The focus is firmly on issues of dynastic succession and transmission of power, as may be seen from the importance granted by Wace to the rule of King Belin (who, with his brother Brennes, is said to have conquered Rome) and the

19 See Geffrei Gaimar, Estoire, ed. Short, p. xlvi. However, this parallel might not be entirely positive, as Arthur in the Estoire is responsible for the coming to power of the usurper of the throne of Haveloc's father; see G. Wheeler, "Kingship and the Transmission of Power in Geffrei Gaimar's Estoire des Engleis", unpublished PhD thesis, University of Sheffield, 2017 .

20 On these fragments, see P. Damian-Grint, The New Historians of the Twelfth-Century Renaissance: Inventing Vernacular Authority, Woodbridge, 1999, pp. 61-65, and more recently, B. Barbieri, "La Geste de Bretuns en alexandrins (Harley Brut): Une traduction de l'Historia aux teintes épiques", in H. Tétrel and G. Veysseyre (eds.), L'Historia regum Britannie et les "Bruts" en Europe, Tome I, Traductions, adaptations, réappropriations (XII ${ }_{-}$ $X V I^{e}$ siècle) (Rencontres 106, Civilisation médiévale, 12), Paris, 2015, pp. 141-55.

21 For a full list of surviving manuscripts and fragments of the Roman de Brut, see J. Blacker, with the collaboration of G.S. Burgess, Wace: A Critical Bibliography, St Helier, 20o8, pp. 6-9. 
passage of dominion to the English effected by the pagan invader Gurmund episodes which all display varying amounts of expansion and elaboration of the poet's main sources. ${ }^{22}$ The outlook is predominantly didactic with a bias toward religious history, a characteristic also of his main source, the First Variant Version of the $D G B$, on which much of the Roman de Brut is based. Wace clearly thought of his work as authoritative scholarship, not fiction, despite the use of amplificatory devices such as descriptions or direct speech and additions of material that the modern reader might more readily associate with romance. ${ }^{23}$ In this, Wace was following the cue of Geoffrey of Monmouth himself, who in turn was ostensibly following the conventions of classical Latin historiography, which also include descriptions and set speeches.

The Norman poet consistently recognizes the entertainment value of the material, while its political implications are underplayed. The $P M$, touching on sensitive issues for the Anglo-Norman kings, is thus omitted entirely. The reason given by Wace for this decision is ostensibly of a scholarly nature: $\mathrm{Ne}$ vuil sun livre translater / Quant jo nel sai interpreter; / Nule rien dire nen vuldreie / Que si ne fust cum jo dirreie (pp. 399-40o, 1l. 7539-42). ${ }^{24}$ The literal translation of this extract is: "I do not wish to translate his book because I do not know how to interpret it; I would not want to say something about it that might not be as I said." Rather than transmit potentially faulty information to his reader, Wace excised the entire Book. This decision results in the loss of an important dimension of Geoffrey's work. Where, in the $D G B$, the $P M$ creates a bridge between the past, present, and future of a beloved homeland, the focus of Wace's Roman de Brut is now the faded past of an alien culture. The poet's emotional distance toward the ancient British people whose history he recounts is further expressed in his dismissal of the Welsh (p. 778, 1l. 14851-54) as degenerate and unworthy descendants of their great ancestors, adding moral condemnation to Geoffrey's picture of political decline. ${ }^{25}$

The exotic aura of Wace's Britain is enhanced by his adding to Geoffrey's already wondrous account of the reign of King Arthur the mention of the Round Table: because of rivalry between his noble barons, "Arthur made the Round Table, about which the Bretons tell many tales." ${ }^{26}$ In this first attested reference to Arthur's Round Table, Wace takes pains to dismiss these tales as fables,

\footnotetext{
22 See F. Le Saux, A Companion to Wace, Cambridge, 2005, pp. 94-102.

23 See Damian-Grint, The New Historians, esp. pp. 85-142.

24 All quotes of the Roman de Brut are from Wace, Roman de Brut, ed. I.D.O. Arnold, Le Roman de Brut de Wace, 2 vols., Paris, 1938-40.

$25 \quad D G B$, xi.207.587-6oo.

26 Wace, Roman de Brut, ed. Arnold, vol. 2, p. 46o, ll. 9751-52: "Fist Artur la Runde Table / Dunt Bretuns font mainte fable."
} 
and therefore inferior to his own work; yet he also recognizes in them a kernel of truth that he, as a historian, can identify. The creation of the Round Table and the stories attached to it are thus explicitly dated to a twelve-year window within Arthur's rule, when the great conqueror enjoyed an extended period of peace after having regained control over Britain and subdued Scotland and Scandinavia. These stories of merveilles pruvees, "marvels" (p. 515, l. 9789), and adventure (p. 515, l. 979o) are thus based in fact, even though they have been retold so often that they have become legendary. The existence of a factual core at the heart of these tales is stressed by Wace, who insists that they are "neither all lies nor all truth, neither all frivolous nor all wise". ${ }^{27}$ This is not a wholesale debunking of such stories; they certainly exaggerate what actually happened, but they nevertheless relate to "real" events that took place at a very specific point of the reign of a supposedly real king. Arthur thus becomes comparable with an Alexander the Great or a Charlemagne, making his tales worthy of written transmission.

Geoffrey's narrative offers tales of chivalry, conquest, and giant-killing; to this, Wace adds the influence of women in periods of peace. When the warlike Cador expresses his joy at the thought of going to war with Rome, Gawain counters with the praise of peace: "Peace is good after war, the land is more beautiful and the better for it; it's very good to have fun, and love affairs are good. For love and for their beloved, knights perform deeds of chivalry."28 The link between drueries, "love", and chevaleries, "chivalry", gives this passage a courtly coloring that fits well with the reputation of Gawain as a seducer of ladies in the later romance tradition. ${ }^{29}$ The main point here, however, is that peace is both transient and desirable. Love is just one of a number of benefits of peacetime, mentioned after the land's increased prosperity (p. 563, l. 10768) and the joys of gaberies, "light-hearted leisure". Moreover, within the cycle of war, love provides the motivation for knights to keep up with their military

27 Wace, Roman de Brut, ed. Arnold, vol. 2, p. 515, ll. 9793-94: "Ne tut mençonge, ne tut veir, / Ne tut folie ne tut saveir".

28 Wace, Roman de Brut, ed. Arnold, vol. 2, pp. 563-64, ll. 10767-72: "Bone est la pais emprès la guerre / Plus bele et mieldre en est la terre; / Mult sunt bones les gaberies / $\mathrm{E}$ bones sunt les drueries. / Pur amistié e pur amies / Funt chevaliers chevaleries."

29 For different readings of this very rich passage, see A. Putter, "Arthurian Literature and the Rhetoric of Effeminacy", in F. Wolfzettel (ed.), Arthurian Romance and Gender: Masculin/ feminine dans le roman arthurien medieval, Amsterdam and Atlanta, 1995, pp. 34-49, esp. p. 44; and M.B. Schichtman, "Gawain in Wace and Layamon: A Case of Metahistorical Evolution", in L.A. Finke and M.B. Schichtman (eds.), Medieval Texts and Contemporary Readers, Ithaca, NY and London, 1987, pp. 103-19. 
training, in anticipation of the next military campaign. ${ }^{30}$ The chevaleries of the knights are not just gratuitous display or mere tokens of affection.

Though Wace is at ease depicting female characters, his treatment of them is not noticeably influenced by the fin'amor of Old Provençal lyrical poetry, neither do we find in his work a celebration of female beauty comparable to Gaimar's description of Ælfthryth. There is little evidence of idealization; instead, one can discern a tendency toward what the present-day reader might see as a form of realism that can be traced back to Wace's hagiographical works. In Wace's Life of St Margaret of Antioch, the effects of the torture inflicted on the saint are thus described without restraint, from the blood flowing from her wounds (pp. 196-97, ll. 188-92) to the exposed entrails hanging out of her martyred body (pp. 200-01, ll. 274-78). ${ }^{31}$ A comparable bluntness can be observed in the Roman de Brut in the depiction of Tonwenne, the elderly mother of Belin and Brennes, who interposes herself between the two warring brothers, pointing to the breasts that had once fed them. The queen mother is not merely described as being old, we are told that her breasts are "withered and hairy with age". ${ }^{2}$ The beauty of younger women, on the other hand, is referred to in a perfunctory and vague manner, and love intrigues only appear where they are also found in Wace's sources. The occasional mention in the French poem of a bride's high lineage says more about the political value of the match than about the lady herself, and the feelings of the characters remain unexplored. ${ }^{33}$

The Roman de Brut cannot therefore be considered a courtly romance. In this respect, Wace is simply following his source material. The $D G B$ is predominantly a narrative of power struggles, punctuated by conflict, battles, and warfare, with a religious dimension provided by regular synchronisms of the British past with biblical events. After the conversion to Christianity of the British people, the defense of their faith against pagan enemies is a recurrent theme: Wace, who had a distinguished record as a hagiographer, would doubtless have been particularly sensitive to this aspect of his source. It is significant

30 On the cycle of war and peace in the $D G B$ and its translations and adaptations, see A. Lynch, "Peace is good after war': The Narrative Seasons of English Arthurian Tradition", in C. Saunders, F. Le Saux, and N. Thomas (eds.), Writing War: Medieval Literary Responses to Warfare, Cambridge, 2004, pp. 127-46.

31 Wace, Conception Nostre Dame, trans. J. Blacker, G.S. Burgess, and A.V. Ogden, Wace, The Hagiographical Works: The 'Conception Nostre Dame' and the Lives of St Margaret and St Nicholas (Studies in Medieval and Reformation Traditions, 169 / Texts and Sources, 3), Leiden, 2013, pp. 196-97 and 200-01.

32 Wace, Roman de Brut, ed. Arnold, vol. 2, p. 148, l. 2724: "flaistres de vieillesce e pelues".

33 See G.S. Burgess, "Women in the Works of Wace", in G.S. Burgess and J. Weiss (eds.), Maistre Wace. A Celebration: Proceedings of the International Colloquium held in Jersey, 10-12 September 2004, St Helier, 2006, pp. 91-106, at pp. 94-98. 
that outside of the Arthurian section, the major additions in the Roman de Brut relate to what might be termed the spiritual history of the land: the prophecy of Teleusin announcing the birth of Christ (p. 26o, ll. 4855-76); the destruction of the town of Cirencester by the pagan Gurmund, emblematic of his destruction of Christianity (pp. 707-13, ll. 13529-632); or anecdotes of the mission of St Augustine of Canterbury, such as the punishment of the people of Dorchester, who had mocked the saint by hanging fish tails on his clothes, and thereafter bore tails themselves (pp. 718-19, ll. 13713-44). ${ }^{34}$ Wace's sensitivity to theological and doctrinal aspects is also perceptible in his reshaping of the prayer of St Oswald before the battle of Heavenfield (pp. 756-57, ll. 144459-71), foregrounding repentance rather than asking for protection in battle. ${ }^{35}$

The prevalence of military episodes in the material of the Roman de Brut would lead one to expect the poem to draw upon the phraseology and conventions of the Old French epic, the chanson de geste, of which the Song of Roland is the most celebrated example. While Wace certainly was familiar with the genre, there is little evidence that he made use of it in composing his work. Stylistically, the chanson de geste is typically composed in stanzas (laisses) of a varying number of lines, usually of ten syllables, linked by the one rhyme, whereas the Roman de Brut is composed in rhyming octosyllabic couplets. The battle scenes do share with the chanson de geste a number of motifs and formulae, but these could equally be attributed to Geoffrey's own use of epic motifs in these passages. In addition, the Roman de Brut distinguishes itself from both the Galfridian narrative and the chanson de geste by the emotional distance of the narrator, who recounts events in a relatively impartial manner. This contrasts sharply with the openly partisan stance of the narrator in the $D G B$, where there is no doubt as to where sympathies should lie. ${ }^{36}$

Wace appears to have been consciously creating his own poetic and narrative idiom when adapting his source material, with a predominantly didactic and scholarly intent designed to enhance its authority. He thus transmits Geoffrey of Monmouth's work to the French-speaking world as "serious" yet entertaining history, while the apparently dismissive passage in the Roman de Brut mentioning the popular tales of Arthur also contains a vindication of these

\footnotetext{
34 Wace, Roman de Brut, ed. Arnold, vol. 2, pp. 718-19, ll.13715-43. On this episode, see Le Saux, A Companion to Wace, pp. 98-99, 116-20, and 145; see also ead., "Wace as Hagiographer", in Burgess and Weiss (eds.), Maistre Wace. A Celebration, pp. 139-48.

35 Oswald's prayer is very much focused on protection from a cruel enemy in both the $D G B$, xi.199.448-51, and the First Variant Version, ed. Wright, p. 185, §199.

36 These points are made in L'Estoire de Brutus. La plus ancienne traduction en prose française de l'Historia Regum Britannie de Geoffroy de Monmouth, ed. G. Veysseyre (Textes littéraires du Moyen Age, 33), Paris, 2014, pp. 103-08.
} 
narratives. The legitimacy of the Matter of Britain for those Anglo-Norman and French writers exploring the emerging genre of courtly romance had been established. By the end of the century, Jehan Bodel, in his Chanson des Saisnes, counts the Matter of Britain among the three narrative matières appropriate for literary development, alongside the Matter of France and the Matter of "Rome la Grant". ${ }^{37}$

The mid 115os, when the Roman de Brut was being composed, was a period of literary innovation. The figure of Alexander the Great was inspiring vernacular literary production from the first third of the 12 th century already, ${ }^{38}$ and narrative poems in French, on non-religious themes, were being commissioned by the Anglo-Norman royal court. The oldest surviving romances are a trilogy of romans d'antiquité: Roman de Thèbes (c.1150), Roman d'Enéas (1155-60) and Roman de Troie (116o-65) ${ }^{39}$ The subject matter of these three romances is recognizably drawn from Greco-Roman narratives: the Roman de Thèbes is an adaptation of Statius's Thebaid, by an anonymous author from Poitou; the Éneas, composed by an anonymous Norman cleric, is loosely based on Virgil's Aeneid; while the Roman de Troie, by Benoît de Sainte-Maure, uses the accounts of two supposed eyewitnesses of the war of Troy, The Fall of Troy, attributed to Dares Phrygius, and A Record of the Trojan War (Ephemeris belli Troianni), attributed to Dictys Cretensis. This material is therefore scholarly and of high status, a fact stressed by the author/narrator of the Roman de Thèbes, who projects himself as heir to Homer, Plato, Virgil, and Cicero. ${ }^{40}$ These texts have in common with Wace's Roman de Brut their historical subject matter, but display a heightened degree of rhetorical and stylistic adornment, with a fondness for the device of ekphrasis, the elaborate verbal description of visual objects, such as paintings or embroideries. The description of the tent of King Adraste of Argos in the Roman de Thèbes (pp. 294-300, ll. 4300-85) is a good example of this feature. Made out of blue and red silk covered with floral embroidery,

37 Jehan Bodel, La chanson des Saisnes, ed. A. Brasseur, La chanson des Saisnes (Textes littéraires français, 369), 2 vols., Geneva, 1989, vol. 1, p. 3, ll. 6-11.

38 The first of these texts to have come down to us, in monorhymed octosyllabic laisses, was written in the south of France by Alberic of Pisançon; only 105 lines of this work, which deal with Alexander's early deeds, survive. Alberic's work was recast in decasyllabic laisses around 1160, and then in the 1170s gave rise to three further poems which were combined around 1180 into a complete romance in dodecasyllabic lines by Alexandre de Paris: Le Roman d'Alexandre. On these texts, see Les Romans d'Alexandre: aux frontiers de l'épique et du romanesque, ed. C. Gaullier-Bougassas (Nouvelle bibliothèque du Moyen Age, 42), Paris, 1998.

39 On these texts and their place in the development of the romance genre, see F. Mora-Lebrun, L'Énéide mediévale et la naissance du roman, Paris, 1994.

Le Roman de Thèbes, ed. and trans. F. Mora-Lebrun, Paris, 1995, p. 44, ll. 5-6. 
the tent's panels are decorated with paintings: on one panel, a mapamunde, a pictorial representation of the earth, lavishly embellished with gold and precious stones, comprising the five climatic zones and all the cities, kingdoms, and sovereigns within them; on another, the seasons and the twelve months of the year, alongside the laws upheld by the king's ancestors; and on a curtain, pictures of leopards, bears, and lions. Such instances of ekphrasis are ornamental, but also function as an indirect means of characterization: ${ }^{41}$ the wondrous tent of King Adraste reflects the quasi-universal ambit of his authority and his duties as upholder of the laws established by his ancestors, as much as it is evidence of his wealth as king of Argos.

An important novelty in the romans d'antiquité is the influence of the Latin writer Ovid. Descriptive passages such as Adraste's tent draw upon models found in the Metamorphoses, while Ovid's Art of Love provides the inspiration for what will become the hallmark of the courtly romance: an interest in, and careful exploration of, the feelings of the protagonists. ${ }^{42}$ The heroes of these narratives remain warriors whose deeds take place on the battlefield, yet a prominent role is now given to their relations with female characters, who are depicted in an idealized manner. In sharp contrast to Wace's decrepit Tonwenne, the elderly queen Jocaste is depicted in the Roman de Thèbes as a dignified and statesmanlike sovereign. The same Roman de Thèbes adds to its main source, Statius's Thebaid, a whole new love affair, between Antigone and Parthénopée. The foregrounding of the heroes' sentiments is particularly in evidence in the final section of the Roman d'Enéas (p. 496, 1l. 8109-10335), where the nascent love of Eneas and Lavinia overshadows chivalric deeds.

The 12th-century Arthurian romances all have Geoffrey of Monmouth's DGB as an implicit sub-text, but they rarely draw directly upon the work. The Arthur of the 12th-century romances has little in common with the great conqueror of Geoffrey's narrative. The focus, as hinted by Wace in his reference to the fables of the Round Table, is on the adventures of Arthur's knights; the king is above all an observer and an enabler, whose court is a largely ceremonial locus. ${ }^{43}$ Such is also the case in what might be the first Arthurian stories to have come down to us in the French language, in Marie de France's Lais. ${ }^{44}$ This collection of twelve

41 On medieval ekphrasis, see V. Allen, "Ekphrasis and the Object", in A.J. Johnston, E. Knapp, and M. Rouse (eds.), The Art of Vision. Ekphrasis in Medieval Literature and Culture, Columbus, 2015, pp. 17-35.

42 R. Jones, The Theme of Love in the Romans d'Antiquité, London, 1972, esp. pp. 30-42.

43 D. Maddox and S. Sturm-Maddox, "Erec et Enide: The First Arthurian Romance", in Lacy and Grimbert (eds.), A Companion to Chrétien de Troyes, pp. 103-19, at p. 103.

44 Quotes are from Marie de France, Lais, ed. K. Warnke and trans. L. Harf-Lancner, Lais de Marie de France, Paris, 199 o. 
short narratives in octosyllabic couplets, probably composed in the 116os, is presented by the narrator/poet as being adaptations from tales sung by the "Bretons". One of these lais, "Lanval", is located at Arthur's court, while another, "Chievrefueil", features the star-crossed lovers Tristan and Yseut, whose adventures were absorbed by an early date into the Arthurian Matter of Britain. ${ }^{45}$ In "Chievrefueil", the Arthurian backdrop would only have been grasped by readers already familiar with the Tristan legend as a whole, as the tale does not take place at Arthur's court or involve the king in any way. In "Lanval", which is set at Arthur's court and features a judicial hearing presided over by the king, the Arthurian world is a far cry from the glory depicted by Geoffrey of Monmouth or Wace. Arthur in "Lanval" comes over as distant and unjust, neglecting to reward a young retainer and easily manipulated by a faithless queen. In this lai, the feudal bond is secondary to issues of appropriate behavior in a courtly society and in affairs of the heart. Lanval, a foreigner, does not mix well and does not spend his money wisely, ending up destitute. His problems are solved by a fairy mistress who magically provides him with all his financial and emotional needs, on condition that her existence remain a secret. Guinevere takes on the role of a temptress, who, when spurned, accuses Lanval of having slighted her by claiming that the plainest of his beloved's handmaidens was more beautiful than she. Lanval, called upon to justify himself in front of Arthur's tribunal, is saved at the last moment by the arrival of the fairy mistress who vindicates him and takes him away to her fairy realm. The powerful character in this story is unmistakably the fairy lover, not the king.

Fairy magic was clearly an important feature of the tales of Arthur circulating in 12th-century Europe. Wace's parenthesis in his Roman de Rou, a history of the dukes of Normandy composed between 1160 and the early 1170 , ${ }^{46}$ gives us an insight into these fables. In an aside to a list of William the Conqueror's allies, some of whom are said to come from the area of Brocéliande, Wace admits to having been bitterly disappointed when he visited the fountain of Barenton in the fabulous forest of Brocéliande, the setting of many a Breton tale (vol. 2, p. 121, 1l. 6374) and home to fairies and wonders. The supposed qualities of this fountain were such that when hunters wished to refresh themselves in summer, they would pour water on the stone next to the spring. This would cause it to rain over the forest (vol. 2, p. 122, ll. 6377-89). Needless to say, Wace failed

45 T. Hunt and G. Bromiley, "The Tristan Legend in Old French Verse", in G.S. Burgess and K. Pratt (eds.), The Arthur of the French. The Arthurian Legend in Medieval French and Occitan Literature (Arthurian Literature in the Middle Ages, 4), Cardiff, 2006, pp. 112-34.

46 All references are from Wace, Roman de Rou, ed. A.J. Holden, Le Roman de Rou de Wace, 2 vols., Paris, 1973 . 
to make it rain, nor did he find any fairies or marvels; he witheringly states, "I went there a fool, a fool I returned." 47 The marvel of the fountain which causes rain to fall if its stone slab is splashed with water reappears in a very similar form in the Arthurian romance of Yvain (c.1177), composed by Chrétien de Troyes, the poet who is credited with having invented the genre. ${ }^{48}$

The romance of Yvain can be seen as paradigmatic of the Arthurian romance. ${ }^{49}$ It opens on the Whitsun festivities at Arthur's court. The knight Calogrenant relates his shameful defeat at the hands of the defender of a wondrous fountain in the forest of Brocéliande. His cousin Yvain vows to avenge him and sets out to seek the fountain, where he pours a whole basinful of water on the stone slab (Versa seur le perron de plain / De l'yaue le bachin tout plain, p. 112, 11. 80o-01). The ensuing storm of wind and rain summons the protector of this fontaine perillouse, "perilous fountain" (p. 112, l. 808); Yvain kills him in the ensuing fight and marries his beautiful widow.

While a fund of motifs in the Arthurian romances are thus clearly borrowed from these marvelous tales, the narratives themselves are informed by the conventions established by the romans d'antiquité. Even Marie de France's Lais, which arguably remain structurally closer to the oral tales they rework than do Chrétien's romances, show evidence of cultural hybridity, both in the nature of the marvels featured in them and in the stylistic devices used. ${ }^{50}$ The cross-cultural approach of Marie de France is explicitly flagged up in certain lais, which are given alternative titles in French, a Brittonic language, and even English. Her tale of the nightingale taken as excuse by a lady for rising in the middle of the night to talk with her lover, and consequently killed by her irate husband, is, we are told, called L'Aüstic by the Breton/British, russignol in French, and nihtegale in English (p. 210, 1l. 1-6). These vernacular roots are moreover refracted through the prism of Latinate culture. The first of the collection of lais, "Guigemar", thus has a hero with a Brittonic-sounding name who embarks on a magical ship to be cured from a hunting wound, but the description of the bed within the ship, with its carved golden ornamentation a l'uevre

47 Wace, Roman de Rou, ed. Holden, vol. 2, p. 122, l. 6396: "fol m'en revinc, fol i alai."

48 References to Yvain are from Chrétien de Troyes, Yvain, ed. and trans. D.F. Hult, Le Chevalier au lion ou Le Roman d'Yvain. Édition critique d'après le manuscript B.N. fr 1433, Paris, 1994. On Chrétien de Troyes, see D. Kelly, "Chrétien de Troyes", in Burgess and Pratt (eds.), The Arthur of the French, pp. 135-85, esp. pp. 135-37.

49 This aspect is analysed by L. Spetia, Li conte de Bretaigne sont si vain et plaisant. Studi sull'Yvain e sul Jaufre, Soveria Mannelli, 2012, pp. 11-119.

50 On Marie de France and her Arthurian lais, see M.T. Bruckner and G.S. Burgess, "Arthur in the Narrative Lay", in Burgess and Pratt (eds.), The Arthur of the French, pp. 186-214, esp. pp. $186-98$. 
Salemun (p. 34, l. 171), is both technical and evocative of the roman d'antiquité..$^{51}$ The journey is made necessary by a curse laid on the hero (a common theme in medieval Celtic literature), but the lady he falls in love with is imprisoned in a tower decorated with a painting representing Venus burning le livre Ovide, "the book of Ovid" (p. 38, l. 239) - probably Ovid's Remedies of Love - and the two lovers explore their nascent feelings in the Ovidian tradition.

Chrétien de Troyes' Erec and Enide, composed c.117o and therefore the oldest Arthurian romance to have come down to us, ${ }^{52}$ also bears the mark of stylistic cross-fertilization. In particular, magical wonders are partly rationalized. Erec's coronation robes, described in great detail over some 70 lines (pp. 508-12, 1l. 6729-68o1), thus features depictions of Geometry, Mathematics, Music, and Astronomy, the four areas of the quadrivium, encompassing the knowledge of the natural world. Macrobius is twice mentioned as an authority vouching for the accuracy of description, yet the robe itself is the work of four fees, created "with great skill and mastery".53 The de-eroticization and attendant rationalizing of the fairy figure as a craftsperson may suggest a degree of discomfort on Chrétien's part with his material, which he will implicitly disavow in his Lancelot or Le Chevalier de la charrette (c.1177), recounting the efforts of the Round Table (in particular Lancelot) to free the captive Guinevere from her abductor Méléagant. This story-line, which recalls the scene depicted on the Arthurian archivolt of Modena Cathedral and has as its hero the archetypical courtly lover, was apparently imposed on the poet by his patroness Marie of Champagne. ${ }^{4}$ Chrétien left it unfinished, entrusting its completion to Godefroi de Leigni (p. 466, 1l. 7102-12).55

$5^{1}$ On the precise nature of the engraving technique thus referred to, see G.D. West, "Luevre Salomon", Modern Language Review 49 (1954), 176-82.

$52 \quad$ Maddox and Sturm-Maddox, "Erec et Enide", pp. 103-19.

53 Maddox and Sturm-Maddox, "Erec et Enide", p. 5o8, ll. 6736-37: "Par grant sens et par grant maistrie".

54 Chrétien de Troyes, Le Chevalier de la charrette, ed. and trans. C. Méla, Le Chevalier de la charrette ou le Roman de Lancelot, Paris, 1992, p. 46, 1l. 24-29. How exactly to read this prologue is a matter of debate. See M.T. Bruckner, "Le Chevalier de la Charrette: That Obscure Object of Desire, Lancelot", in Lacy and Grimbert (eds.), A Companion to Chrétien de Troyes, pp. 137-55, at pp. 140-42.

55 This is also the case of Chrétien's Perceval ou le Conte du graal which, if the Middle Welsh analogue Peredur is anything to go by, was based on a tale that could only be transposed into the courtly idiom with some difficulty; see I. Lovecy, "Historia Peredur ab Efrawg", in R. Bromwich, A.O.H. Jarman, and B.F. Roberts (eds.), The Arthur of the Welsh: The Arthurian Legend in Medieval Welsh Literature (Arthurian Literature in the Middle Ages, 1), Cardiff, 1991, pp. 171-82. It is however also possible that Perceval was interrupted by the death of the poet. 
Ultimately, the romances have little in common with the Arthurian world portrayed by Geoffrey of Monmouth. Arthur's Whitsun court is a ritual meeting-place, providing a framework around which to weave the adventures of his knights, but the king himself remains a shadowy character. When Calogrenant tells his tale to Yvain and the court in Erec and Enide, Arthur is actually fast asleep. The matter of the Arthurian romance focuses on the Round Table and the ability of its knights to seek out and resolve crises of a military, political, and sentimental nature. Hence Jehan Bodel's description in Chanson des Saisnes of the Matter of Britain as vain et plaisant, "pleasant froth" (p. 3, l. 9), as opposed to the worthy didacticism of the sage et de san aprenant, "wise and teaching of wisdom" (p. 3, l. 10), Matter of Rome or the truth-bearing Matter of France (p. 3, l. 11).

The Arthurian romances of the 12th century are in constant dialogue with the clerical tradition informing the roman d'antiquité and narratives of the marvels of the East, which they supplement with a magical twist: an aspect in evidence in Chrétien de Troyes' Cligès, where the Byzantine East is made to meet the Arthurian West in the person of the Greek prince Alexander, who goes to serve at Arthur's court where he meets his wife. Their son eventually becomes emperor of Constantinople. These fashionable literary developments also influenced the way Geoffrey's material was treated by translators and adaptors. Fragments, some of them substantial, of verse translations other than by Wace are evidence that Geoffrey's gallery of villains and heroes was viewed to some extent through the lens of epic and romance even by scholars. Most of the surviving fragments or partial redactions are versions of the $P M$, composed to fill the gap left by Wace, but five important remnants of broader narratives have also come down to us, from the late 12 th and early 13 th centuries: ${ }^{56}$ the Bekker fragment, in alexandrines, recounting the story of Stonehenge, ${ }^{57}$ the Harley Brut (five fragments, London, British Library, Harley 1605), also in alexandrines, which include the story of Stonehenge and the $P M ;{ }^{58}$ London, British Library, Harley 4733 (254 lines in octosyllabic couplets) which tells of

56 See P. Damian-Grint, "Arthur in the Brut tradition", in Burgess and Pratt (eds.), The Arthur of the French, pp. 101-11, at pp. 101-04.

57 Edited in "Le fragment Bekker et les anciennes versions françaises de l'Historia Regum Britanniae", ed. S. Lefèvre, Romania 109 (1988), 225-46.

$5^{8}$ Fragments 1-4 are transcribed by P. Damian-Grint, "Vernacular History in the Making: Anglo-Norman Verse Historiography in the Twelfth Century", unpublished PhD thesis, University of London, 1994; Fragment 5 is edited in "The Harley Brut: An Early French Translation of Geoffrey of Monmouth's Historia Regum Britanniae", ed. B. Blakey, Romania 82 (1961), 44-70. See also B. Barbieri, 'Una traduzione anglo-normanna dell'Historia Regum Britannia': la geste des Bretuns in alessandrini (Harley Brut)", Studi mediolatini e volgari 57 (2011), 163-76. 
Arthur's campaign against Colgrim and the Saxon return after their defeat at Lincoln; ${ }^{59}$ the Royal Brut (6,237 lines in octosyllabic couplets; London, British Library, Royal 13 A. xxi), ${ }^{60}$ covering the narrative from the beginning up to the conception of Arthur, at which point it switches to Wace's text; and the Munich Brut (4,18o lines in octosyllabic couplets; Munich, Bayerische Staatsbibliothek, Gall. 29), from the founding of Britain and the early kings, up to the foundation of Rome, which is the object of a lengthy interpolation. ${ }^{61}$ These fragments display marked variations, both stylistically and in their approach to their material.

The Harley Brut has an experimental flavor, with a quasi-epic meter: alexandrine lines, grouped in rhyming laisses of varying lengths evocative of the chanson de geste; however, it also features a remarkable instance of ekphrasis, a feature more commonly associated with romance, as we have seen. Some 116 lines (six laisses) are devoted to an elaborate description of Arthur's tent, which has detailed scenes painted on each of its panels. ${ }^{62}$ The first panel (laisses CLXII and CLXIII) shows Moses leading the children of Israel out of Egypt through the Red Sea; his receiving of the Tables of the Law on Mount Sinai; his anger when discovering that his people were worshipping the golden calf; his shattering of the Tables of the Law and subsequent prayer for mercy for his errant people. The narrator stresses the completeness of this pictorial narrative, which, we are told, omits none of the adventures or hardships experienced by the Israelites in the desert (p. 51, 1l. 2735-37). The scene of Moses's anger ends on a reassuring apostrophe to the audience before showing the wrongdoers being consumed by the ground beneath them. The second panel (laisse CLXIV) depicts the anointing of David by Samuel and the slaying of Goliath; on the third panel (laisse CLXV) is an episode from the history of Troie la cité, "the city of Troy" (p. 52, l. 2780), the story of Ulysses and the enchantress Circe, whose potions turned men into animals (p. 53, l. 280o); the fourth panel (laisse CLXVI) tells the story of Judith and Holofernes, culminating in the decapitation of the king. The visual narrative of these panels is clarified for the viewer

59 Edited in “A 12th-century Anglo-Norman Brut Fragment (MS BL Harley 4733, f. 128)", ed. P. Damian-Grint, in I. Short (ed.), Anglo-Norman Anniversary Essays (Anglo-Norman Text Society Occasional Publications Series, 2), London, 1993, pp. 87-104.

6o Edited in An Anglo-Norman Brut (Royal 13.A.xxi), ed. A. Bell (Anglo-Norman Text Society, 21-22), Oxford, 1969 .

61 Der Münchener Brut, ed. K. Hofmann and K. Vollmöller, Der Münchener Brut, Gottfried von Monmouth in französischen Versen des xii. Jahrhunderts, Halle, 1877. For a more recent edition, see also "An Edition of the Munich Brut", ed. P.B. Grout, unpublished PhD thesis, University of London, 1980.

62 All quotes from Fragment 5 are drawn from “The Harley Brut", ed. Blakey. Blakey (pp. 4850) convincingly situates this passage within the context of Arthur's French campaign. 
by inscriptions above the scenes depicted, a detail stressed by the narrator: the names of different figures in the first panel are inscribed above them: "Above them the text was written, giving the name and appearance of each character"; the events of the second panel are written in engraved golden letters highlighted in black: "All this is shown by the letters carved with a chisel, the gold then filled in with black"; 63 while the scenes of the third and fourth panel are explained to the viewer by a text above the image (lettre surescrite, p. 53, ll. 2800 and 2825).

These panels contain a double narrative strand, combining biblical references and classical tradition. The first three panels provide a symbolic summary of the strengths of the good king, of which Arthur may be seen as an example: a law-giver, like Moses, who guides his people with justice yet mercy; the Lord's anointed, fighting for a just cause, and therefore favored by divine providence against overwhelming odds, like David; and a wise man like Ulysses, able to discern evil and resist the temptation of self-indulgence. The fourth panel may be read as a warning, illustrating the fate of the king lacking in these qualities: an inglorious death, like that of Holofernes at the hand of a woman. Such a program is conventional in its didacticism, while the story of Ulysses, presented as a tale from the fall of Troy, is an indirect homage to the supposed Trojan origins of the British - and thus of the owner of the tent, King Arthur himself.

The depiction of the door of the tent which follows contrasts sharply with the heavily didactic pictorial program contained on its panels. The door is openly magical in properties - it denies access to anyone with bad intentions and is described in terms that evoke both the luxurious wonders of the East and the Arthurian "merveilleux": adorned with 1000 precious stones encased in solid gold, and set with an immensely valuable wondrous mirror by fairies (p. 54, ll. 2835-36). This unexpected intrusion of romance motifs into a passage that is otherwise epic, in its outlook as well as its verse form, brings an element of tension to the avowed program of the tent as a whole, if only because fairy attributes and evil are very much equated on the third panel, in the person of the enchantress Circe. Circe is described as possessing the extreme physical beauty associated with fairies: "She was the daughter of the sun, a woman of great beauty. There was no woman as beautiful as she in the whole realm", while practicing black magic: "She had total mastery of necromancy." ${ }^{4}$ The

63 "The Harley Brut", ed. Blakey, p. 51, ll. 2738-39: "Par desus esteit fait la lettre de l'Escriture / Ki rendeit a chascun sun nom et sa figure"; p. 52, ll. 2776-77: "Tot ço mustre la lettre entaillé a cisel, / E après entraite enz en l'or a nüel."

64 "The Harley Brut", ed. Blakey, p. 52, ll. 2785-86: "fille esteit del soleil, femme de grant bealté / N'aveit si bele femme en trestut le regné"; p. $5^{2}$, 1. 279o: "sout de nigromance tot a sa volenté". 
possession of magical fairy artifacts thus does not sit well with the stern moral and religious message of the tent panels: the description of Arthur's tent in the Harley Brut blends two very different types of motifs.

The Harley fragments are unusual in that the surviving early French translations of the $D G B$ tend to switch to Wace's version of the Arthurian episode. ${ }^{65}$ This is significant, as the pre-Arthurian section of the $D G B$ does not offer a comparable scope for translators to amplify their source narrative with romanceinspired features. The reign of King Leir, with its psychological exploration and scenes of court ceremonial as well as of conflict and warfare, certainly offered potential for imaginative expansion in the romance idiom, but this did not happen to any significant extent. ${ }^{66} \mathrm{~A}$ striking exception to this general observation, however, is offered by the so-called Munich Brut.

The Munich Brut makes a number of important additions and modifications to Geoffrey's account of the founding of Britain that are evidence of a didactic intent. The work opens with a prologue describing the island of Britain (pp. 1-3, ll. 1-9o). The aftermath of the fall of Troy and Eneas's union with Lavine is then expanded with material from accepted authorities, named as Virgil, Cato, and Isidore. ${ }^{67} \mathrm{~A}$ spirited refutation of Virgil's account of the outcome of the battle between Eneas and Turnus (p. 6, 1l. 195-214) signals to the reader that the poet is well-informed and critical of his authorities, while adept at interpreting his sources. Virgil, we are told, lied selunc la letre, "in the literal sense" (p. 6, l. 211), because he wanted to flatter Caesar Augustus, but his work is still truth-bearing in its own way, as it is philosophical rather than informative in nature: "It must be given a different meaning, for his books are all about philosophy." ${ }^{\prime 6}$ The Munich Brut's interest in Roman history is again evidenced in a lengthy interpolation (pp. 96-108, 1l. 3711-4178) repeating some of the Eneas material in order to anchor the story of the birth of Romulus and Remus and the foundation of Rome to the chronology of Britain. This is the work of a scholar, or someone who wishes to be perceived as such. Matrimonial policy is in evidence, with an effort to enhance the dignity of the noble brides, and

65 The other exception to this observation is London, British Library, Harley 4733, fol. 128, which recounts Arthur's coming to power and first campaign against the Saxons. See "A 12th-century Anglo-Norman Brut Fragment", ed. Damian-Grint.

66 Rewriting in this episode tends to be focused on speeches. For an edition and contemporary French translation of the Leir episode in Geoffrey of Monmouth, Wace, Lazamon, the Munich Brut, and the Royal Brut, see Le Roi Leïr. Versions des XII e et XIII e siècles, ed. F. Zufferey and trans. G. Nussbaumer, Paris, 2015.

67 Der Münchener Brut, ed. Hofmann and Vollmöller, pp. 6-7, ll. 195, 216, 261, 262.

68 Der Münchener Brut, ed. Hofmann and Vollmöller, p. 6, ll. 212-14: "altre sens i covient metre / Quar cho est tot philosophie, / Quantque ses livres sinefie.” 
therefore, indirectly, of their spouses; Eneas's powerful rival Turnus is strikingly dismissed in the prophecy of Latinus's soothsayer as a mere local man, a païsant de la contree (p. 4, 1. 128).

However, more space is devoted to psychological analysis than might have been expected. The quandary in which the captured Anacletus finds himself, having to choose between betrayal or death, is presented with some understanding by the narrator (pp. 19-20, ll. 730-43), while Brutus's blandishments of Ignogen on the ship taking her away from her homeland are motivated by the fact that he wishes to secure her affections (de li ameir vuelt avoir gratie, p. 29, l. 1120). A glimpse into the more mundane aspects of life is afforded by the mention that before arming himself to go to battle with King Gaiffiers of Poitou, Brutus has a bite to eat (dinne se un poi, p. 44, l. 1694). The space afforded to the private thoughts and actions of the characters is not the only evidence of the influence of the aesthetic of the romance. The description of the captive Estrild and her effect on Locrin is inescapably in the courtly idiom. The girl is the daughter of a king, and her incomparable beauty is described in terms that are evocative of the courtly lyric: whiter than ivory, snow, or the lily flower (p. 57, 1l. 2205-07). Locrin's response is that of the typical Ovidian lover, sighing, besotted, and in thrall to Venus. His symptoms, described over 12 lines, end with a reference to the god of love wounding the hero with his arrow "The god of love has dealt roughly with him, with his arrow he has wounded him" - that would not be out of place in a lai or a courtly romance. ${ }^{69}$

The attraction of the romance is perhaps even more in evidence in the locus amoenus where Rea Sylvia falls asleep in a state of partial undress, in the interpolation recounting the birth of Romulus and Remus at the end of the Munich Brut (p. 101, ll. 3907-22). If this passage had been transmitted as an isolated fragment, it is unlikely the reader would have associated it with a Brut. Much of it is conventional: lo riu cleir de la fontaine, "the clear waters of a fountain" (p. 101, l. 3911), the abundance of grass and flowers (p. 101, 1l. 3914-15), the protective shade offered by the trees (p. 101, l. 3917), and sweet birdsong, in particular that of the nightingale and the parrot (p. 101, 1l. 3921-22). The nightingale, associated with both love and brutal rape, is particularly appropriate, as Mars will rape the girl in her sleep and sire on her the twins Romulus and Remus. The singing parrot, however, is a touch of exotic extravagance betraying the extent of the stylistic attraction of romance on the redactor at this point.

The Brut fragments show that the influence of romance themes and motifs on 12th-century translators and adapters of the $D G B$ was strong, but not

69 Der Münchener Brut, ed. Hofmann and Vollmöller, p. 58, 1l. 2219-20: "Li deus d'amor l'ot mal menei, / De sa sajete el cors nafrei." 
consistent or pervasive. Amplification tends to occur at points of contact with other narrative traditions: classical accounts of the foundation of Rome in the early history of Britain, and the Arthurian romance in the account of the reign of Arthur. Something that is missing in these fragments, and which would have offered a valuable point of reference to assess this phenomenon, is the end of Arthur's reign. Arthur's journey to Avalon to be cured of his wounds and the promise of his return must have been an important feature of the stories hinted at by Geoffrey of Monmouth in his prologue. Where the $D G B$ merely states that Arthur was taken to the island of Avalon to have his mortal wounds tended (xi.178.81-82), Wace explicitly mentions in his Roman de Brut (p. 693, ll. 13279-81) the belief of the "Bretun" that Arthur will return from Avalon, which he treats with cautious skepticism. Wace's English translator, Lazamon, in the early 13th century, further fills in the picture with the fairy healer Argante, who will cure the wounded king in Avalon. ${ }^{70}$ That the legend was strongly implanted and carried genuine political resonances may also be deduced from the publicity around the exhumation of Arthur's supposed remains in Glastonbury in $1191 .^{71}$

The apparent lack of interest of 12th-century romances for the life and death of Arthur cannot therefore be attributed to the absence of narrative material, as much as to the fact that the Arthurian romance of this period is not truly about Arthur at all. As noted by Kelly, "all twelfth and thirteenth-century Arthurian verse romances seem to take Chrétien's romances as models to emulate, rewrite or correct": ${ }^{72}$ and as we have seen, the king at the head of the Round Table in the romances of Chrétien de Troyes has only tenuous links with Geoffrey's Arthur. We have to wait for the beginning of the 13th century to see the emergence of narratives of Arthur the heroic warrior-king, within narrative cycles roughly structured on a chronological principle. ${ }^{73}$ Arthur's twelve years of peace - and, crucially, his involvement in the Quest for the Holy Grail, an

70 Lazamon, Brut, ed. G.L. Brook and R.F. Leslie, Layamon: Brut. Edited from British Museum MS Cotton Caligula $A$ ix and British Museum MS Otho Cxiii, 2 vols., London, 1963-78, vol. 2, p. 75 o, ll. $14277-82$, and $14288-97$, where, contrary to Wace, the English poet appears to be validating the belief in Arthur's return. Lazamon's newborn Arthur is also said to be magically endowed by elves with the gifts of power, long life, and generosity (ll. 9607-15).

71 See J.P. Carley, "Arthur in English History", in W.R.J. Barron (ed.), The Arthur of the English. The Arthurian Legend in Medieval English Life and Literature (Arthurian Literature of the Middle Ages, 2), Cardiff, 1999, pp. 47-57, esp. pp. 48-5o.

72 Kelly, "Chrétien de Troyes", p. 393.

73 See F. Bogdanow and R. Trachsler, "Rewriting Prose Romance: The post-vulgate Roman du Graal and related texts", in Burgess and Pratt (eds.), The Arthur of the French, pp. 342-92. 
invention of the continuators of Chrétien de Troyes' Perceval ${ }^{44}$ - are replaced within the context of his entire lifespan, a moment of glory that makes the tragedy of his death even more acute.

Around the same time that Geoffrey of Monmouth's Arthur is adopted as a fully-fledged, complex literary character, so do adaptations and continuations of the $D G B$ start to distance themselves from the stylistic approach evidenced in the verse Brut fragments. The Prose Bruts, whether in French or in English, increasingly underplay the mirabilia contained in the $D G B$; from the $13^{\text {th }}$ century onwards, the cultural dimension to Geoffrey's vision of the past is pruned down and replaced with a predominantly political outlook, with very little allowance for flights of fancy. ${ }^{75}$ The careful blend of legend and history created by Geoffrey of Monmouth in the $D G B$ has been unpicked and reshaped for a new age.

74 See R.T. Pickens, K. Busby, and A.M.L. Williams, "Perceval and the Grail:The Continuations, Robert de Boron and Perlesvaus", in Burgess and Pratt (eds.), The Arthur of the French, pp. 213-73.

75 See F. Le Saux, "La Grande Bretagne, patrie des sciences? La représentation des technologies scientifiques dans Geoffroy de Monmouth et Layamon", in Tétrel and Veysseyre (eds.), L'Historia regum Britannie, pp. 157-75, esp. pp. 174-75. 